\title{
Anesthesia Mumps after The Cesarean Section in Pregnant Woman
}

\author{
İsmail Katı1', Zehra Kurdoğlu², Uğur Göktaș', O Çağatay Aytekin¹, Serhat Avcu
}

Yuzuncu Yil University, Medical Faculty, Department of Anesthesiology and Reanimation ${ }^{1}$, Obstetric and Gynecology ${ }^{2}$ and Radiology 3 , Van, Turkey

Eur J Gen Med 2011;8(4):342-344

Received: 26.04.2010

Accepted: 04.08.2010
Correspondence: Dr. İsmail Katı Yüzüncü Yıl üniversitesi Tıp Fakültesi Anesteziyoloji ve Reanimasyon $A D$ 65100-Merkez Van, Türkiye Tel: 0905337210160

E-mail:katiismail@yahoo.com

\begin{abstract}
Anesthesia mumps is characterized by acute transient swelling of the parotid gland association with general anesthesia. We presented a 25 years old pregnant woman with anesthesia mumps after 24 hours Cesarean section, and discussed treatment of anesthesia mumps and differential diagnosis. 25 years old woman underwent to operation for Cesarean section. Her Medical history had no chronic disease, and no allergies. Her mental and psychological status, neurological, other systematical examination findings and laboratory values were normal. General anesthesia was administered. Twenty four hours after the extubation, a large swelling of right more than left parotid region expanding down to the mandibular angle was noted. In conclusion we suggest that especialy obstetrical cases should be performed gently intubation and extubation and used medications should be attention. In additioal, anesthesia mumps of patients may fully recover within a few days without any treatment or with treatment.
\end{abstract}

Key words: anesthesia mumps; general anesthesia; pregnant women

\section{Hamile Bayanda Sezeryan Sonrası Gelișen Anestezi Kabakulağı}

Genel anesteziye bağlı parotis bezinin akut geçici șişmesi ile karakterizedir. Biz , 25 yașında hamile bir bayanda, sezaryen ameliyatından 24 saat sonra gelișen anestezi kabakulağının tedavisi ve ayırıcı tanısı irdeleyeceğiz. 25 yaşında kadın sezaryen operasyonuna alındı. Anamnezinde kronik bir hastalık ve alerji öyküsü yoktu. Zihinsel ve psikolojik durumu, nörolojik ve diğer sistem muayene bulguları ve laboratuar değerleri normaldi. Genel anestezi uyguland. Ekstübasyondan yirmi dört saat sonra sağ parotis bölgede sola göre daha büyük olmak üzere mandibular açının așağına doğru genișleyen șişlik mevcuttu. Sonuç olarak, özellikle obstetrik olgularda nazikçe entübasyon ve ekstübasyon yapılmalı ve kullanılan ilaçlara dikkat edilmesi gerektiği kanaatindeyiz. Ilave olarak Anestezi kabakulağı tedavi ile veya tedavisiz birkaç gün içerisinde iyileșebilir.

Anahtar kelimeler: Anestezi kabakulağı, genel anestezi, hamile bayan 


\section{INTRODUCTION}

Anesthesia mumps is characterized by acute transient swelling of the parotid gland association with general anesthesia. Anesthesia mumps is an uncommon postoperative complication and a rare clinical entity and It is a benign and noninfectious complication $(1,2)$. The swelling and enlargement are transient and may last for several minutes to several days (2). There has been no report of anesthesia mumps in obstetric surgical literature and after postoperative 24 hours as yet. We presented a 25 year young pregnant women with anesthesia mumps after 24 hours Cesarean section, and discussed treatment of anesthesia mumps and differential diagnosis.

\section{CASE}

25 years old woman underwent to operation for Cesarean section. Her Medical history had no chronic disease, and no allergies. Her mental and psychological status, neurological, other systematical examination findings and laboratory values were normal. General anesthesia was induced with iv fentanyl iv $0.5 \mu \mathrm{g} . \mathrm{kg}-1$, propofol iv 2.5 mg.kg-1 and vecuronium $0.1 \mathrm{mg} . \mathrm{kg}-1$ after routine anesthesia monitoring. After orotracheal intubation, an endotracheal tube was fixed on the right side of mouth. Anesthesia was maintained with sevoflurane (1-1.5\% end tidal concentration) in 50\% nitrous oxide and $50 \%$ mixture of oxygen and fentanyl iv $50 \mu \mathrm{g}$. The patient was placed in the supine position. The surgical procedure was uneventful. The total blood loss was about $450 \mathrm{ml}$. The operation was lasted about 45 minutes. His vital signs remained stable during the operation, Neuromuscular block was reversed with were administrated intravenously neostigmine $1.5 \mathrm{mg}$ and atropine $0.5 \mathrm{mg}$. The patient was extubated without any problem and recovery was uneventful. Twenty four hours after the extubation, a large swelling of right more than left parotid region expanding down to the mandibular angle was noted (Figure 1). The patient complained of moderate bilateral swelling and mild pain in this area. There were mild difficulty of swallowing, and mild dyspnea. Clinical examination showed diffuse edema over the parotid gland and intraoral examination seen that the orifice of the Stensen's duct was open. The overlying skin was not erythematous, and warm. There was no palpable crepitation. The body temperature was also normal. Serum amylase level and white blood cell were normal. We performed ultrasonography, which showed bilateral submandibular glands and right parotid gland enlargement and edema (Figure 2). Besides, chest roentgenogram had no evidence of pneumothorax. The patient received non-steroidal anti-inflammatory drug two days. No antibiotic was given. Her clinical symptoms and signs resolved for 3 days postoperative. The patient was discharged 4 days after the operation.

\section{DISCUSSION}

Acute transient swelling of the parotid gland after surgical procedures performed under general anesthesia was first reported by Attas et al (3). Insidence of anesthesia mumps was reported that five in 3000 following endotracheal anesthesia by Matsuki et al (4). Authors reported that still unclear the etiology of the anesthesia mumps. Among the implicated mechanisms are trauma, straining and/or coughing during anesthesia, vascular congestion, and venous engorgement of the head and neck and parasympathetic anesthetic drugs (etc. antihistamines, and succinylcholine), and atropine, and dehydration, and mechanical blockage of the parotid duct by intubation and fixation of the endotracheal tube or head stripping and obstruction of glandular excretory ducts by position, calculi, or thickened secretion (5-8).

Mutaf et al. reported that combination of increased saliva secretion with insufficient drainage, the saliva accumulates in the gland and causes swelling and pain (2). Other causes of acute postoperative parotid swelling, which need to be eliminated from the differential are viral parotitis, pneumoparotitis, acute allergic conditions, and acute postoperative bacterial parotitis may be wrongly diagnosed (10-12). Liu et al. (13) believe the presence of the patient's underlying disease, choice of anesthetic drugs, surgical position, operative site (such as head and neck surgery) and induction methods (such as endotracheal tube, laryngeal mask inadequate insertion and fixation) may all contribute to the development of acute swelling of the parotid glands during general anesthesia.

Although in the area over the course of parotid duct is not anything such as edema, redness, inflamation, and a purulent discharge draining from the orifice, in our patient was administerd only atropine and endotracheal intubation from among predisposing factors. 


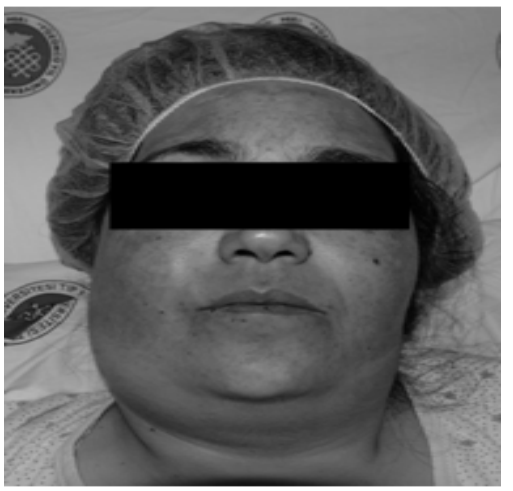

Figure 1. Swelling of the right parotid gland

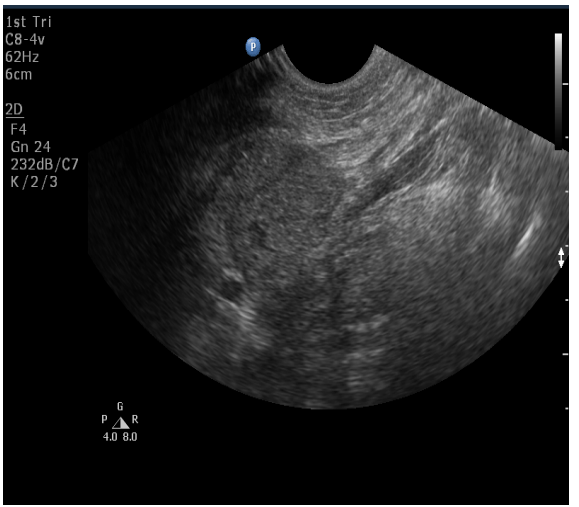

Figure 2. The right parotid gland enlargement and edema

2. Mutaf M, Büyükgüral B. An unusual postoperative complication: anesthesia mumps. Eur J Plast Surg 2007; 29:335-8

3. Attas M, Sabawala PB, Keats AS. Acute transient sialoadenopathy during induction of anesthesia. Anesthesiology 1968; 29:1050-2

4. Matsuki A, Wakayama S, Oyama T. Acute transient swelling of the salivary glands during and following endotracheal anaesthesia. Anaesthesist 1975; 24:125-8

5. Kiran S, Lamba A, Chhabra B: Acute pansialadenopathy during induction of anesthesia causing airway obstruction. Anesth Analg 1997;85:1052-3.

6. Rice DH. Saliva gland physiology. Otolaryngol Clin North Am 1977; 10:273-85.

7. Shields $H M$, Soloway RD, Long WB et al. Bilateral recurrent parotid swelling after endoscopy. Gastroenterology 1977; 73:164-5.

8. Slaughter RL. Parotid gland swelling developing during peroral endoscopy. Gastrointest Endosc 1975;22:38-9.

9. Wakayama S. Salivary gland swelling developing during and immediately after general anesthesia. Anesthesiology 1968;22:14-7.

10. Brodie HA, Chole RA. Recurrent pneumosialadenitis: a case presentation and new surgical intervention. Otolaryngol Head Neck Surg 1988;98:350-3.

11. Calcaterra TC, Lowe J. Pneumoparotitis. Acta Otolaryngol 1965; 52:784-9.

12. Hemenway WG, English GM. Surgical treatment of acute bacterial parotitis. Postgrad Med 1971; 50:114-9.

13. Liu FC, Liou JT, Li AH, Chiou Hung Jr. Day YJi. Chang Acute Unilateral Parotid Glands Enlargement Following Endotracheal General Anesthesia: Report of Two Cases Gung Med J 2007;30:453-7. 